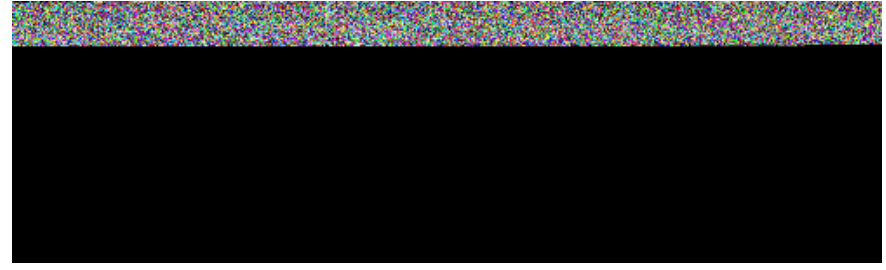

This information is current as of April 26, 2023.

\title{
"No Man is an Island" John Donne
}

C.C.T. Lim and K. Tsuchiya

AJNR Am J Neuroradiol 2020, 41 (6) E40

doi: https://doi.org/10.3174/ajnr.A6544

http://www.ajnr.org/content/41/6/E40 


\section{"No Man is an Island"}

\section{John Donne}

W e read with great interest the recent Editorial by Mahajan and Hirsch ${ }^{1}$ in the American Journal of Neuroradiology (AJNR). At a time when the coronavirus disease 2019 (COVID19) pandemic is raging, it provides a helpful and succinct summary and reminds us to play our part as good citizens as an informed and steadying influence on our colleagues, nurses, technologists, patients, families, and community.

As neuroradiologists, readers of the AJNR might also be concerned about the possible CNS manifestations or complications in this novel disease. Outbreaks of zoonotic viral diseases affecting the CNS have happened previously: The Nipah virus outbreak in 1998 was spread from bats via pigs to humans and caused respiratory and encephalopathic symptoms. MR imaging patterns included either extensive involvement of the cortex, temporal lobe, and pons, or multiple small $(<1 \mathrm{~cm}$ in maximum diameter) abnormalities involving the subcortical and deep white matter, corpus callosum, and brain stem, especially visible on diffusion-weighted images. ${ }^{2}$ In a case report of a patient with sequential organ failure, including meningoencephalitis from the Ebola virus, MR imaging showed multiple punctate lesions in the corpus callosum, cerebral white matter, and spinal cord, some with restricted diffusion, consistent with microvascular occlusion and ischemia. ${ }^{3}$ However, the literature on imaging of CNS involvement in the Coronaviridae family, which also includes the Severe Acute Respiratory Syndrome (SARS) and the Middle East Respiratory Syndrome (MERS), is more limited. In the previous SARS outbreak in 2003, CT findings in 5 patients who developed large-artery ischemic stroke were reported, with the recommendation to be vigilant in future outbreaks for thrombotic complications in critically ill patients, especially if intravenous immunoglobulin is being used for treatment. ${ }^{4}$

Similarly, neurologic symptoms have been observed in a preprint report on severely ill patients in Wuhan during the current COVID-19 outbreak, including acute cerebrovascular diseases, consciousness impairment, and skeletal muscle symptoms; unfortunately, no CT or MR imaging has been described thus far. ${ }^{5}$ Case reports of encephalitis and meningitis have also appeared in the lay press in both Beijing, China, ${ }^{6}$ and Yamanashi, Japan. ${ }^{7}$ We await the full publication of these results, to respond appropriately.

Unlike previous, localized outbreaks among smaller clusters of patients, this current COVID-19 epidemic affects us all person- ally: Neuroradiologists are responding to a constant barrage of official directives, planning for potential disruptions, and adjusting to patient case mixes as they occur. We urge good citizen neuroradiologists to learn as much as we can, report and share accurate data on patients undergoing CNS imaging, keep up with fastmoving developments, and help one another. In a worldwide pandemic, we are all in this together and we are all citizens of the world. Therefore, we would be wise to heed the famous quotation from John Donne, "No man is an island...Any man's death diminishes me, because I am involved in mankind. And therefore, never send to know for whom the bell tolls; It tolls for thee."

\section{REFERENCES}

1. Mahajan A, Hirsch JA. Novel coronavirus: what neuroradiologists as citizens of the world need to know. AJNR Am J Neuroradiol 2020 Mar 20. [Epub ahead of print] CrossRef Medline

2. Lim C, Sitoh YY, Hui F, et al. Nipah viral encephalitis or Japanese encephalitis? MR findings in a new zoonotic disease. AJNR Am J Neuroradiol 2000;21:455-61 Medline

3. Chertow DS, Nath A, Suffredini AF, et al. Severe meningoencephalitis in a case of Ebola virus disease: a case report. Ann Intern Med 2016;165:301-04 CrossRef Medline

4. Umapathi T, Kor AC, Venketasubramanian N, et al. Large artery ischaemic stroke in severe acute respiratory syndrome (SARS). $J$ Neurol 2004;251:1227-31 CrossRef Medline

5. Mao L, Wang M, Chen S, et al. Neurological manifestations of hospitalized patients with COVID-19 in Wuhan, China: a retrospective case series study. medRxiv 2020 CrossRef https://www.medrxiv.org/ content/10.1101/2020.02.22.20026500v1. Accessed March 21, 2020

6. New research sparks debate over whether Coronavirus can infect the nervous system. Caixin https://www.caixinglobal.com/2020-03-06/newresearch-sparks-debate-over-whether-coronavirus-can-infect-thenervous-system-101524986.html. Accessed March 21, 2020

7. Shah S. Can novel Coronavirus cause meningitis? Japan has the answer. International Business Times March 8, 2020. https://www. ibtimes.sg/can-novel-coronavirus-cause-meningitis-japan-has-answer40647. Accessed March 21, 2020

(1) C.C.T. Lim

Department of Neuroradiology National Neuroscience Institute Duke-NUS Graduate Medical School Singapore

(D) K. Tsuchiya

Department of Radiology Saitama Medical Center, Saitama Medical University Kawagoe City, Saitama, Japan 